\title{
Reduced expression of exocytotic proteins caused by anti-cholinesterase pesticides in Brachionus calyciflorus (Rotifera: Monogononta)
}

\author{
Pérez-Legaspi, IA. ${ }^{a}$, Rico-Martínez, . $^{b}$, and Quintanar, JL. ${ }^{c *}$ \\ aDivisión de Estudios de Posgrado e Investigación, Instituto Tecnológico de Boca del Río, \\ Km. 12 Carr. Veracruz-Córdoba, Boca del Rio, Veracruz, C.P. 94290, Mexico

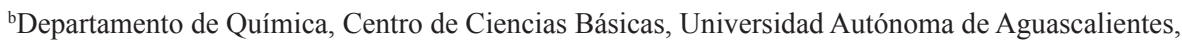 \\ Ave. Universidad 940, Aguascalientes, Ags., CP. 20131, Mexico \\ 'Departamento de Fisiología y Farmacología, Centro de Ciencias Básicas, Universidad Autónoma de Aguascalientes, \\ Ave. Universidad 940, Aguascalientes, Ags., CP. 20131, Mexico \\ *e-mail: jlquinta@correo.uaa.mx
}

Received: January 17, 2014 - Accepted: March 14, 2014 - Distributed: August 31, 2015

(With 3 figures)

\begin{abstract}
The organophosphate and carbamate pesticides methyl-parathion and carbaryl have a common action mechanism: they inhibit acetylcholinesterase enzyme by blocking the transmission of nerve impulses. However, they can alter the expression of exocytotic membrane proteins (SNARE), by modifying release of neurotransmitters and other substances. This study evaluated the adverse effects of the pesticides methyl-parathion and carbaryl on expression of SNARE proteins: Syntaxin-1, Syntaxin-4 and SNAP-23 in freshwater rotifer Brachionus calyciflorus. Protein expression of these three proteins was analyzed before and after exposure to these two pesticides by Western Blot. The expression of Syntaxin-1, Syntaxin-4 and SNAP-23 proteins in B. calyciflorus significantly decreases with increasing concentration of either pesticides. This suggests that organophosphates and carbamates have adverse effects on expression of membrane proteins of exocytosis by altering the recognition, docking and fusion of presynaptic and vesicular membranes involved in exocytosis of neurotransmitters. Our results demonstrate that the neurotoxic effect of anticholinesterase pesticides influences the interaction of syntaxins and SNAP-25 and the proper assembly of the SNARE complex.
\end{abstract}

Keywords: SNARE, pesticide, anticholinesterase, neuroexocytosis, rotifer.

\section{Redução da expressão de proteínas de exocitose causados por pesticidas anti-colinesterase em Brachionus calyciflorus (Rotifera: Monogononta)}

\begin{abstract}
Resumo
Os pesticidas organofosforados e carbamatos metil- paration e carbaril tem um mecanismo de ação comum: eles inibem a enzima acetilcolinesterase, bloqueando a transmissão dos impulsos nervosos. No entanto, eles podem alterar a expressão de proteínas de membrana de exocitose (SNARE), através da modificação da libertação de neurotransmissores e outras substâncias. Este estudo avaliou os efeitos adversos dos pesticidas metil- paration e carbaril sobre a expressão de proteínas SNARE: Sintaxina -1, Sintaxina-4 e SNAP-23 em rotíferos de água doce Brachionus calyciflorus. A expressão destas três proteínas foi analisada antes e depois da exposição a estes dois pesticidas por Western Blot. A expressão das proteínas Sintaxina-1, Sintaxina-4 e SNAP-23 em B. calyciflorus diminui significativamente com o aumento da concentração de ambos os pesticidas. Isto sugere que os organofosfatos e carbamatos têm efeitos adversos sobre a expressão de proteínas de membrana de exocitose, alterando o reconhecimento, de encaixe e fusão de membranas pré-sinápticas e vesiculares envolvidas na exocitose de neurotransmissores. Nossos resultados demonstram que o efeito neurotóxico de pesticidas anticolinesterásicos influencia a interação de sintaxinas e SNAP-25 e a montagem correta do complexo SNARE.
\end{abstract}

Palavras-chave: SNARE, pesticidas, anticolinesterásicos, neuroexocytosis, rotíferos 


\section{Introduction}

Complex soluble N-ethylmaleimide-sensitive factor attachment protein receptors known as SNAREs, includes target membrane proteins (t-SNAREs) such as proteins associated with synaptosomes of $25 \mathrm{KDa}$ (SNAP-25) and $23 \mathrm{KDa}$ (SNAP-23), Syntaxin-1 and Syntaxin-4 and membranes proteins associated with the secretory vesicle (v-SNARE) such as sinaptobrevin/VAMP. This complex is a packet of four helix bundle of coils, a bundle contributed by sinaptobrevin/VAMP, an additional domain bundle by the Syntaxin and two domains bundle by SNAP-25; mediating the plasma and vesicular membranes fusion (Gerst, 1999; Burgoyne and Morgan, 2003; Suh et al., 2010; Wu et al., 2013). SNAP-23 is considered homologous to SNAP-25, being able to replace it during exocytosis in neuroendocrine cells. SNAP-23 is involved in functional regulation of postsynaptic glutamate receptors, and is necessary to transfer membrane protein recycling (Suh et al., 2010).

In rotifers, the secretion and intracellular traffic of neurotransmitters, hormones and other substances of neural, endocrine and exocrin cells are carried through the fusion of both presynaptic plasma membrane and vesicular membrane regulated by the SNARE complex (Gerst, 1999; Pérez-Legaspi et al., 2008). In this invertebrates, SNARE proteins Syntaxin-1, Syntaxin-4, SNAP-23 and SNAP-25 have been reported in glandular, reproductive, and nervous systems (Pérez-Legaspi et al., 2008). Therefore, vesicular secretions of various molecules such as chemical messengers are conserved from invertebrates to vertebrates (Burgoyne and Morgan, 2003).

The use of organophosphates and carbamate pesticides have increased due to their low cost, short persistence in the environment, and high efficiency to control a broad spectrum of pests in agriculture, forestry, homes and businesses. Methyl-parathion (O,O-dimethyl O-p-nitrophenyl phosphorothioate) is widely used against various pests, in spite of its restriction from use on agricultural crops (Garcia et al., 2003; Huang and Huang, 2011; Huang et al., 2011). Carbaryl (1-naphthyl $\mathrm{N}$-methylcarbamate) is a carbamate that, due to its low toxicity in mammals, is commonly used to control lice, termites, ticks and flies (Relyea and Mills, 2001).

However, only 1 out of $3 \%$ of an agrochemical might reach its biological target. The remainder residues in the environment become a potential risk for human health and for non-target organisms (Huang and Huang, 2011). Pesticides such as Methyl-parathion from agricultural run-off are capable of altering the structure of the aquatic community, decreasing biodiversity of benthic macroinvertebrates (Egler et al., 2012). The toxicity of these pesticides is not specific to the target organism, although they are designed to inhibit the activity of acetylcholinesterase (AChE), disabling hydrolysis of the neurotransmitter acetylcholine (ACh) leading to its accumulation in the synapse cholinergic neuromuscular junctions, and causing various neurotoxic effects by the overstimulation of this system (Cranmer, 1986; Relyea and Mills, 2001; Garcia et al., 2003; Newman and Unger, 2003; Nimmo and McEwen, 2009; Huang and Huang, 2011; Huang et al., 2011; Pérez-Legaspi et al., 2012). Other adverse effects by methyl-parathion involve peroxidation of lipids, protein oxidation, and damage to DNA by oxidative stress by reactive oxygen species (Huang and Huang, 2011; Huang et al., 2011). It also alters cellular processes of growth and differentiation of the nervous system, inhibiting butyrylcholinesterase $(\mathrm{BuChE})$ which is involved in neural development. It also affects the voltage-gated $\mathrm{Ca}$ channels and nicotinic receptors on these cells. In addition to its neurotoxic effects, methyl-parathion affects the liver, muscle, and cardiovascular systems (Garcia et al., 2003).

Toxicity of anti-acetylcholinesterase pesticides, their exposure time and the magnitude of inhibition of AChE in wild organisms, result from changes in behavior to death (Newman and Unger, 2003; Nimmo and McEwen, 2009). In the fish Prochilodus lineatus the organophosphate pesticide dimethoate, $40 \%$ decline larval mobility possibly due to AChE inhibition (Campagna et al., 2006). In the zebrafish Danio rerio neurotoxicity by methyl-parathion causes oxidative damage, alterations in both metabolism and signal transduction, imbalance in the synthesis and degradation of proteins, as well as dysfunction of neural system (Huang and Huang, 2011; Huang et al., 2011). In the cladocerans Daphnia pulex (Dodson et al., 1995; Hanazato and Hirokawa, 2004) and D. magna (Hanazato and Yasuno, 1987; Fernández-Casalderrey et al., 1995), organophosphate and carbamate pesticides alter their population dynamics, disrupting structure and function of the aquatic community. The same effect can be observed in the rotifers Brachionus calyciflorus, B. angularis, and B. patulus exposed to methyl-parathion (Fernández-Casalderrey et al., 1993; Flores et al., 1999; Sarma et al., 2001; Flores et al., 2004) and the rotifer Lecane quadridentata exposed to carbaryl and methyl-parathion (Pérez-Legaspi et al., 2012). Thus, since rotifers are aquatic invertebrates with cholinergic (Nogrady and Alai, 1983; Raineri, 1984; Pineda-Rosas et al., 2005), catecholaminergic (Kotikova 1995), and serotoninergic (Kotikova et al., 2005) nervous system, there are susceptible to toxic effects of these pesticides in the aquatic environment. The impact of pollutants on the distribution of rotifer species, can be decisive in aquatic ecosystems (Medeiros et al., 2010). Therefore, changes in richness and abundance of species can be a signal of environmental deterioration, where the detection the sublethal concentrations of chemicals in aquatic ecosystems can be a suitable indicator to individual analysis of the chemical substance (Egler et al., 2012).

The aim of this study was to evaluate the effects of the anti-cholinesterase pesticides methyl-parathion and carbaryl on the changes in the expression of the exocytotic membrane proteins Syntaxin-1, Syntaxin-4 and SNAP-23 in the rotifer $B$. calyciflorus, thus contributing to the understanding of the mechanism of neurotoxicity caused by these pesticides. 


\section{Material and Methods}

The rotifer Brachionus calyciflorus (PALLAS, 1776) was collected from the reservoir of the water treatment plant of the Universidad Autónoma de Aguascalientes, in Aguascalientes, México. Its cultivation was maintained for more than two years according to the protocol of Pérez-Legaspi and Rico-Martínez (1998) in one liter flasks with synthetic freshwater EPA Medium (96 mg $\mathrm{NaHCO}_{3}$, $60 \mathrm{mg} \mathrm{CaSO} \cdot 2 \mathrm{H}_{2} \mathrm{O}, 60 \mathrm{mg} \mathrm{MgSO}_{4}$, and $4 \mathrm{mg} \mathrm{KCl}$ per liter) at $\mathrm{pH} 7.5$ (EPA, 1985) and fed the green algae Nannochloris oculata (UTEX strain LB2194) in Bold's basal medium (Nichols, 1973), at $25^{\circ} \pm 2^{\circ} \mathrm{C}$ under a 16:8 hours (light: darkness) in a bioclimatic chamber (Revco Scientific, Asheville, NC, USA). All media were prepared with deionized water obtained from Labconco Water Pro PS System (Labconco, Kansas City, MO, USA). The pesticides used in this study were of the highest purity available: the carbamate carbaryl (Sigma Co. USA) and the organophosphate methyl-parathion (Supelco, Co. USA). Carbaryl was dissolved in acetone (JT Baker Co. USA) prior to use.

Extraction, separation and detection of the membrane proteins of exocytosis of rotifers are carried out according to the protocol of Pérez-Legaspi et al. (2008) with slight modifications. Briefly, 500 rotifers were initially collected through a mesh of $54 \mu \mathrm{m}$ in diameter, placing them in a plastic Petri dish with EPA medium. Then, the rotifers were transferred to $1.5 \mathrm{ml}$ microcentrifuge Eppendorf tubes where were exposed to the pesticides for one hour. The test design included a negative control (EPA medium without toxic), a solvent acetone control, and five different concentrations $(0.5,1,5,10$ and $20 \mathrm{mg} / \mathrm{l})$ of each pesticide evaluated, in a final volume of $1 \mathrm{ml}$ per test, in triplicate. Concentrations series were established according the LC50 values at 48-hours of exposure for carbaryl (13.72 mg/l) and methyl-parathion $(9.49 \mathrm{mg} / \mathrm{l})$, reported previously for the rotifer L. quadridentata (Pérez-Legaspi et al., 2012). Eppendorf tubes with rotifers were centrifuged twice at $14,000 \mathrm{rpm}$ for 10 minutes at $4^{\circ} \mathrm{C}$, placing them in an ice bath to maintain the integrity of the pellet with rotifers, eliminating the supernatant with a micropipette blocking the hole in the tip with a $54 \mu \mathrm{m}$ mesh to prevent aspiration of the rotifers. We added into the rotifer concentrate $30 \mu \mathrm{l}$ of sample buffer [upper buffer ( $0.5 \mathrm{M}$ Trizma-base, $0.4 \%$ SDS at pH 6.8), 10\% SDS, glycerol, bromophenol, and $\beta$-mercaptoethanol]. Rotifer's samples are heated to $100^{\circ} \mathrm{C}$ for 5 minutes and then to $60^{\circ} \mathrm{C}$ for 15 minutes. This treatment resulted in samples of rotifer proteins ready for electrophoresis. The electrophoresis was performed by add $30 \mu \mathrm{l}$ of rotifer protein sample (1 negative control and 5 concentrations of each pesticide), a positive control (brain of rat) and the low molecular weight marker (RW), by triplicate. Also, the quantification of the total protein concentration was in 500 individuals $(n=3)$ of the same species using the Bradford assay (Kruger, 2002) to evaluate the amount of total protein.
Electrophoresis was performed in SDS-PAGE (13.5\%) according to the Protocol of the Laemmli buffer system (Laemmli, 1970) with slight modifications (Pérez-Legaspi et al., 2008). The stacking gel contains upper buffer (0.5 M Trizma-base, $0.4 \%$ SDS at pH 6.8), and resolving gel contains lower buffer (1.5 M Trizma-base, $0.4 \% \mathrm{SDS}$ at $\mathrm{pH} 8.8$ ). These solutions were prepared with deionized water, acrylamide, $10 \%$ ammonium persulfate, and TEMED, respectively. Rainbow ${ }^{\mathbf{T M}}$ Low Molecular Weight Marker (Amersham Biosciences UK) was used as molecular weight protein marker. Gel was run in a vertical mini-protean system (Bio-Rad, Hercules, CA, USA). After electrophoresis, proteins obtained from polyacrylamide gel were electrotransfered to a PVDF (polyvinyldene difluoride) membrane (Sigma, St. Louis, MO, USA), according to the protocol of Towbin et al. (1979) with slight modifications (Pérez-Legaspi et al., 2008). The western blot was performed by blocking the PVDF membranes in solutions composed of TBS milk $5 \%$ (0.5 M NaCl, $20 \mathrm{mM}$ Tris- $\mathrm{HCl} \mathrm{pH} 7.5)$ for 1 hour at room temperature and incubated overnight at $4^{\circ} \mathrm{C}$ with rabbit polyclonal primary antibodies (Sigma, St. Louis, MO, U.S.A.) such as anti-Syntaxin-1 (1:1000), anti-Syntaxin-4 (1:500), and anti-SNAP-23 (1:500) in blocking buffer. After several rinses with TBS and TTBS (0.5 M NaCl, 20 mM Tris- $\mathrm{HCl}$ pH7.5 with $0.01 \%$ Tween-20), the membranes were incubated by two hours with ALP (alkaline phosphatase-conjugated secondary antibody), and with the secondary antibody against rabbit polyclonal antibody anti-Syntaxin-1, anti-Syntaxin-4 and anti-SNAP-23 (Sigma, St. Louis, MO, U.S.A.), diluted $1: 10,000$ in blocking buffer. After several rinsings, ALP activity detection took place in the immunotransfered membrane by 5-bromo-4-chloro-3-indolyl phosphate/nitro blue tetrazolium tablets (Sigma, St. Louis, MO, U.S.A.), to localize bands of interest. The reaction was stopped by immersing the membrane in deionized water and eliminating excess water.

Analysis of the bands from PDVF membrane was performed by mean of densitometry using the program Kodak Digital Science 1D, quantifying the average intensity of the area of interest of each band on the control and the five concentrations of the pesticide in triplicate for each evaluated protein. Average values and its standard deviations were obtained, using the average of the control as $100 \%$ value, and then comparing this value with the five concentrations of the pesticide evaluated. We performed one-way analysis of variance (ANOVA) with $\mathrm{p}<0.01$ level. Statistical analysis was performed using the software STATISTICA 7.0 .

\section{Results}

Total protein concentration of 500 individuals of the rotifer $B$. calyciflorus correspond to $20.1 \pm 12 \mu \mathrm{g}$ of total protein. Rotifer protein samples were separated and analyzed by triplicate using both polyacrylamide electrophoresis and western blot techniques to evaluate expression of the membrane protein of exocytosis Syntaxin-1 (35 KDa), 
Syntaxin-4 (35 KDa) and SNAP-23 (23 KDa) in the rotifer B. calyciflorus exposed for one hour to the pesticide methyl-parathion and carbaryl. Level of expression of the membrane proteins assessed decreases significantly $(p<0.01)$ while increase the concentration of any of the anticholinesterase pesticides, showing an adverse effect at different concentrations in comparison with the control. Figure 1 shows that expression of Syntaxin-1 was reduced at $20 \mathrm{mg} / \mathrm{l}$ of carbaryl, while methyl-parathion decreases expression of this protein at $10 \mathrm{mg} / \mathrm{l}$. In Figure 2, the Syntaxin-4 expression was reduced at $0.5 \mathrm{mg} / 1$ value for carbaryl, while methyl-parathion at $10 \mathrm{mg} / \mathrm{l}$. Therefore, methyl-parathion was able to reduce the expression of proteins of type Syntaxin-1 and Syntaxin-4 at $10 \mathrm{mg} / 1$ on $B$. calyciflorus exposed for one hour to the pesticide. Figure 3 shows that both pesticides evaluated causing an adverse effect at $0.5 \mathrm{mg} / \mathrm{l}$ concentration, causing a decrease in the expression of SNAP-23.

\section{Discussion}

Our study reveals that in spite of being designed to inhibit the enzyme acetylcholinesterase the function of pesticides carbaryl and methyl-parathion have other mechanisms of action. Specifically its neurotoxic effect can reduce expression of the exocytotic membrane proteins: Syntaxin-1, Syntaxin-4 and SNAP-23. These effects might modify the process of recognition, docking, and fusion of the vesicular and plasma membranes, thus disturbing the structure and functionality of the SNARE complex. This can lead to accumulation of vesicles in presynaptic
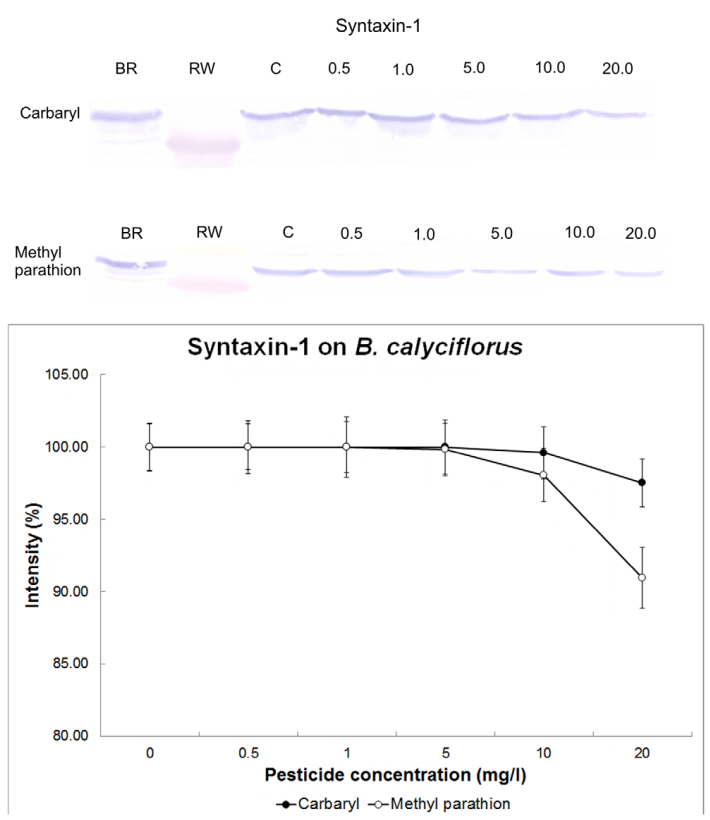

Figure 1. Graph that shows the decrease in the expression of Syntaxin-1 in average percentage and its standard deviation $(\mathrm{p}<0.01)$ assessed in the rotifer Brachionus calyciflorus. Abbreviations: Control (0), concentrations are in $\mathrm{mg} / \mathrm{l}(0.5,1,5,10$ and 20$)$. terminals altering neuroexocytosis and interfering with release of neurotransmitters, hormones, and structural proteins; and then probably by disrupting transmission of nerve impulses in rotifers.
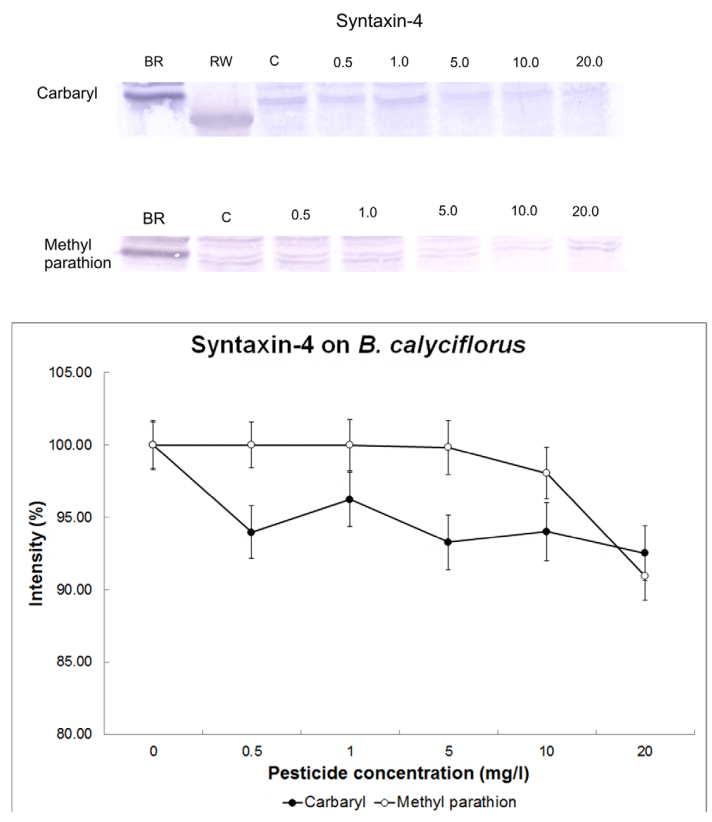

Figure 2. Effect of methyl-parathion and carbaryl on expression of exocytotic membrane protein Syntaxin-4 (35 KDa) in Brachionus calyciflorus. Abbreviations: Control $(0)$, concentrations are in $\mathrm{mg} / \mathrm{l}(0.5,1,5,10$ and 20$)$.
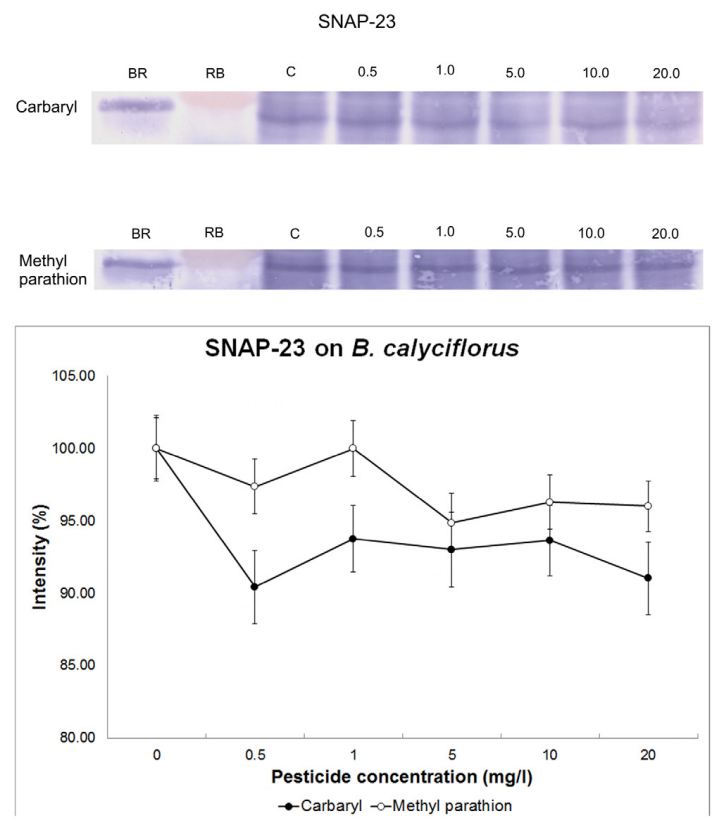

Figure 3. Electrophoretic analysis and graph of the effect of methyl-parathion and carbaryl on expression of exocytotic membrane protein SNAP-23 in Brachionus calyciflorus. Abbreviations: Control (0), concentrations are in $\mathrm{mg} / \mathrm{l}(0.5,1,5,10$ and 20$)$. 
Carbaryl and methyl-parathion caused a decrease in abundance of the membrane proteins of exocytosis evaluated: Syntaxin-1, Syntaxin-4 and SNAP-23 in the rotifer Brachionus calyciflorus (Figures 1-3). In rotifers, reduction of Syntaxin-1, Syntaxin-4 and SNAP-23 might modify the traffic and cellular communication in glandular, reproductive, and nervous systems causing disorders in behavioral, physiological, and biochemical processes. The adverse effect on expression of these proteins might be explained because pesticides may alter the process of protein synthesis. Huang and Huang (2011) mention that methyl-parathion affects the elongation factor $\mathrm{Tu}(\mathrm{EF}-\mathrm{Tu})$ involved in release of aminoacyl tRNA to in A site of the ribosome. In addition, this pesticide causes changes in transcription, affecting the level of expression in proteins important in maintenance of the nervous system, disrupting neural development (Huang et al., 2011). Bhavan and Geraldine (2009) mention that carbaryl interferes with the process of protein synthesis, and suggest protein degradation by carbaryl. Therefore, these pesticides are capable of altering both synthesis and expression of the proteins: Syntaxin-1, Syntaxin-4 and SNAP-23. Also, Huang and Huang (2011) reported adverse effects by methyl-parathion on proteins membrane involved in the response to oxidative stress, signal transduction, metabolism, synthesis and degradation of proteins, neuroplasticity and regeneration, and synaptic transmission.

Carbaryl is able to decrease expression of Syntaxin- 1 at $20 \mathrm{mg} / 1$ (Figure 1) and Syntaxin- 4 at $0.5 \mathrm{mg} / 1$ concentration (Figure 2). While methyl-parathion causes a decrease in expression of both Syntaxins at $10 \mathrm{mg} / 1$ (Figure 1 and 2). The adverse effect on Syntaxins may increase because the pesticides also inhibit synthesis of other proteins closely related to formation of the SNARE complex. Huang and Huang (2011), reported that methyl-parathion alters the abundance of STXBP1 protein (Sec1/Munc-18) in zebrafish (Danio rerio). Burgoyne and Morgan (2003), mention that this protein acts as chaperone of Syntaxin and its activation depends on the interaction Syntaxin-Sec1, regulating the proper assembly of the SNARE complex. However, Toonen et al. (2005), mention that the isoform Munc18-1 is not a classical chaperone required for the operation of Syntaxin-1, because Syntaxin-1 can be assembled in the SNARE complex in the absence of Munc-18-1. However, formation of the SNARE complex can be unstable, non-functional, or assembly can occur in the wrong way. Therefore, methyl-parathion exposure adversely affects membrane proteins of exocytosis by altering the docking and release of synaptic vesicles during intracellular membrane traffic.

The decrease in expression of SNAP-23 by the pesticides studied here was observed at $0.5 \mathrm{mg} / 1$ (Figure 3) in comparison with Syntaxins, SNAP-23 is more susceptible at lower concentrations. Suh et al. (2010) mention that SNAP-23is involved in postsynaptic membrane trafficking events and its alteration decreases expression of NMDA (non-natural aminoacid N-methyl-D-aspartate) receptors of glutamate surface and the amount of current receivers in dendritic spines from hippocampal neurons in culture. Therefore, alteration in SNAP-23 protein affecting communication between presynaptic and postsynaptic cells by neurotransmitter NMDA of glutamate stopping the membrane depolarization of the postsynaptic neuron.

Interaction of Syntaxin and SNAP-25, and subsequent formation of the SNARE complex is essential for transmission of nerve impulses (O'Connor et al., 1997). Their right interaction plays a key role in neuroexocitosis and transmission of nerve impulses. The adverse effect of the pesticides evaluated here can modify expression of these membrane proteins generating defective proteins in their conformation and function, thereby affecting the structure and interaction between Syntaxins, SNAP-25, and possibly sinaptobrevins, making impossible the appropriate formation of the SNARE protein complex and altering the process of recognition, docking, and fusion of vesicular and plasma membranes to perform the neuroexocitosis.

\section{Conclusion}

The expression of membrane proteins of exocytosis of Syntaxin-1, Syntaxin-4, and SNAP-23 was reduced in the rotifer $B$. calyciflorus by exposure to the pesticides carbaryl and methyl parathion. This effect is observed through analysis of western blot and densitometry. These anticholinesterase pesticides affect the appropriate formation of the SNARE complex, and probably result in alteration of the process of recognition, docking, and fusion of vesicular and plasma membranes. As a result, neuroexocytosis and release of substances, secretion of neurotransmitters, hormones, and other proteins important in cellular communication are blocked.

\section{Aknowledgements}

I. A. Pérez-Legaspi acknowledges support from a Consejo Nacional de Ciencia y Tecnología (CONACyT) scholarship No. 136453, and Sistema Nacional de Investigadores (SNI) Expediente 49351.

\section{References}

BHAVAN, PS. and GERALDINE, P., 2009. Manifestation of carbaryl toxicity on soluble protein and histopathology in the hepatopancreas and gills of the prawn, Macrobrachium malcolmsonii. Journal of Environmental Biology / Academy of Environmental Biology, vol. 30, no. 4, p. 533-538. PMid:20120492.

BURGOYNE, RD. and MORGAN, A., 2003. Secretory granule exocytosis. Physiological Reviews, vol. 83, no. 2, p. 581-632. http://dx.doi.org/10.1152/physrev.00031.2002. PMid:12663867.

CAMPAGNA, AF., ELER, MN., ESPÍNDOLA, ELG., SENHORINI, JA., RÊGO, RF. and SILVA, LOL., 2006. Dimethoate 40\% organosphosphorous pesticide toxicity in Prochilodus lineatus (Prochilodontidae, Characiformes) eggs and larvae. Brazilian Journal of Biology $=$ Revista Brasileira de Biologia, vol. 66, no. 2B, p. 633-640. http://dx.doi.org/10.1590/S1519-69842006000400007. PMid:16906295. 
CRANMER, MF., 1986. Carbaryl. A toxicological review and risk analysis. Neurotoxicology, vol. 7, no. 1, p. 247-328. PMid:3086783.

DODSON, SI., HANAZATO, T. and GORSKI, PR., 1995. Behavioral responses of Daphnia pulex exposed to carbaryl and Chaoborus kairomone. Environmental Toxicology and Chemistry, vol. 14, no. 1, p. 43-50. http://dx.doi.org/10.1897/1552-8618(1995)14[43:BR ODPE]2.0.CO;2.

EGLER, M., BUSS, DF., MOREIRA, JC. and BAPTISTA, DF., 2012. Influence of agricultural land-use and pesticides on benthic macroinvertebrate assemblages in an agricultural river basin in southeast Brazil. Brazilian Journal of Biology $=$ Revista Brasileira de Biologia, vol. 72, no. 3, p. 437-443. http://dx.doi.org/10.1590/ S1519-69842012000300004. PMid:22990812.

FERNÁNDEZ-CASALDERREY, A., FERRANDO, MD. and ANDREU-MOLINER, E., 1993. Chronic toxicity of methylparathion to the rotifer Brachionus calyciflorus fed on Nannochloris oculata and Chlorella pyrenoidosa. Hydrobiologia, vol. 255-256, no. 1, p. 41-49. http://dx.doi.org/10.1007/BF00025818.

FERNÁNDEZ-CASALDERREY, A., FERRANDO, MD. and ANDREU-MOLINER, E., 1995. Chronic toxicity of methylparathion to Daphnia magna: effects on survival, reproduction, and growth. Bulletin of Environmental Contamination and Toxicology, vol. 54, no. 1, p. 43-49. http://dx.doi.org/10.1007/BF00196268. PMid:7756784.

FLORES, JLG., SARMA, SSS. and ARAIZA, MAF., 1999. Combined effects of Chlorella density and methyl parathion concentration on the population growth of Brachionus calyciflorus (Rotifera). Bulletin of Environmental Contamination and Toxicology, vol. 62, no. 6, p. 769-775. http://dx.doi.org/10.1007/s001289900938. PMid:10354003.

FLORES, JLG., SARMA, SSS. and NANDINI, S., 2004. Acute and chronic toxicity of the pesticides methyl parathion to the rotifer Brachionus angularis (Rotifera) at different algal (Chlorella vulgaris) food densities. Aquatic Ecology, vol. 38, no. 1, p. 27 36. http://dx.doi.org/10.1023/B:AECO.0000020986.92471.32.

GARCIA, SJ., ABU-QARE, AW., MEEKER-O'CONNELL, WA., BORTON, AJ. and ABOU-DONIA, MB., 2003. Methyl parathion: a review of health effects. Journal of Toxicology and Environmental Health. Part B, Critical Reviews, vol. 6, no. 2, p. 185-210. http:// dx.doi.org/10.1080/10937400306471. PMid:12554434.

GERST, JE., 1999. SNAREs and SNARE regulators in membrane fusion and exocytosis. Cellular and Molecular Life Sciences : CMLS, vol. 55, no. 5, p. 707-734. http://dx.doi.org/10.1007/ s000180050328. PMid:10379359.

HANAZATO, T. and HIROKAWA, H., 2004. Changes in vulnerability of Daphnia to an insecticide application depending on the population phase. Freshwater Biology, vol. 49, no. 4, p. 402-409. http://dx.doi.org/10.1111/j.1365-2427.2004.01191.x.

HANAZATO, T. and YASUNO, M., 1987. Effects of a carbamate insecticide, carbaryl, on the summer phyto- and zooplankton communities in ponds. Environmental Pollution, vol. 48, no. 2, p. 145-159. http://dx.doi.org/10.1016/0269-7491(87)90093-5. PMid:15092693.

HUANG, QY. and HUANG, HQ., 2011. Differential expression profile of membrane proteins in zebrafish (Danio rerio) brain exposed to methyl parathion. Proteomics, vol. 11, no. 18, p. 37433756. http://dx.doi.org/10.1002/pmic.201100084. PMid:21761560.

HUANG, QY., HUANG, L. and HUANG, HQ., 2011. Proteomic analysis of methyl parathion-responsive proteins in zebrafish
(Danio rerio) brain. Comparative Biochemistry and Physiology. Toxicology \& Pharmacology : CBP, vol. 153, no. 1, p. 67-74. http://dx.doi.org/10.1016/j.cbpc.2010.08.009. PMid:20826231.

KOTIKOVA, EA., 1995. Localization and neuroanatomy of catecholaminergic neurons in some rotifer species. Hydrobiologia, vol. 313-314, no. 1, p. 123-127. http://dx.doi.org/10.1007/ BF00025940.

KOTIKOVA, EA., RAIKOVA, OI., REUTER, M. and GUSTAFSSON, MKS., 2005. Rotifer nervous system visualized by FMRF amide and 5-HT immunocytochemistry and confocal laser scanning microscopy. Hydrobiologia, vol. 546, no. 1, p. 239-248. http:// dx.doi.org/10.1007/s10750-005-4203-5.

KRUGER, NJ., 2002. The Bradford method for protein quantification. In WALKER, JM. (Ed.). The Protein Protocols Handbook. Totowa: Humana Press. p. 15-21.

LAEMMLI, UK., 1970. Cleavage of structural proteins during the assembly of the head of the bacteriophage T4. Nature, vol. 227 , p. $680-685$.

MEDEIROS, AMA., BARBOSA, JEL., MEDEIROS, PR., ROCHA, RM. and SILVA, LF., 2010. Salinity and freshwater discharge determine rotifer distribution at the Mossoró River Estuary (Semiarid Region of Brazil). Brazilian Journal of Biology = Revista Brasileira de Biologia, vol. 70, no. 3, p. 551-557. PMid:20730341.

NEWMAN, MC. and UNGER, MA., 2003. Fundamentals of ecotoxicology. Boca Ratón: Lewis Publishers. p. 221-224.

NICHOLS, HW., 1973. Growth media-freshwater. In STEIN, JR. (Ed.). Handbook of phycological methods. Cambridge: Cambridge University Press. p. 7-24.

NIMMO, DR. and MCEWEN, LC., 2009. Pesticides. In CALOW, P. (Ed.). Handbook of ecotoxicology. Malden: Blackwell Scientific Publications. p. 619-667.

NOGRADY, T. and ALAI, M., 1983. Cholinergic neurotransmission in rotifers. Hydrobiologia, vol. 104, no. 1, p. 149-153. http:// dx.doi.org/10.1007/BF00045962.

O'CONNOR, V., HEUSS, C., DE BELLO, WM., DRESBACH, T., CHARLTON, MP., HUNT, JH., PELLEGRINI, LL., HODEL, A., BURGER, MM., BETZ, H., AUGUSTINE, GJ. and SCHÄFER, T., 1997. Disruption of syntaxin-mediated protein interactions blocks neurotransmitter secretion. Proceedings of the National Academy of Sciences of the United States of America, vol. 94, no. 22, p. 12186-12191. http://dx.doi.org/10.1073/pnas.94.22.12186. PMid:9342384.

PÉREZ-LEGASPI, IA. and RICO-MARTÍNEZ, R., 1998. Effect of temperature and food concentration in two species of littoral rotifers. Hydrobiologia, vol. 387-388, p. 341-348. http://dx.doi. org/10.1023/A:1017099906853.

PÉREZ-LEGASPI, IA., MONTOYA-GARCÍA, MR., QUINTANAR, JL., SALINAS, E. and RICO-MARTÍNEZ, R., 2008. Identification of exocytotic membrane proteins in three rotifer species. Hydrobiologia, vol. 600, no. 1, p. 147-154. http:// dx.doi.org/10.1007/s10750-007-9184-0.

PÉREZ-LEGASPI, IA., QUINTANAR, JL. and RICO-MARTÍNEZ, R., 2012. Comparing toxicity endpoints on Lecane quadridentata (Rotifera: Monogononta) exposed to two anticholinesterases pesticides. Environmental Toxicology, vol. 27, no. 9, p. 518-525. http://dx.doi.org/10.1002/tox.20668. PMid:22887767. 
PINEDA-ROSAS, A., SANTOS-MEDRANO, GE., ZAVALAREYNOSO, MF. and RICO-MARTÍNEZ, R., 2005. Identification of acetylcholinesterase receptors in Rotifera. Hydrobiologia, vol. 546, no. 1, p. 249-253. http://dx.doi.org/10.1007/s10750-005-4204-4.

RAINERI, M., 1984. Histochemical investigations of Rotifera Bdelloidea. I. Localization of cholinesterase activity. The Histochemical Journal, vol. 16, no. 6, p. 601-616. http://dx.doi. org/10.1007/BF01003388. PMid:6735744.

RELYEA, RA. and MILLS, N., 2001. Predator-induced stress makes the pesticide carbaryl more deadly to gray treefrog tadpoles (Hyla versicolor). Proceedings of the National Academy of Sciences of the United States of America, vol. 98, no. 5, p. 2491-2496. http:// dx.doi.org/10.1073/pnas.031076198. PMid:11226266.

SARMA, SSS., NANDINI, S. and FLORES, JL., 2001. Effect of methyl parathion on the population growth of the rotifer Brachionus patulus (O. F. Müller) under different algal food (Chlorella vulgaris) densities. Ecotoxicology and Environmental Safety, vol. 48, no. 2, p. 190-195. http://dx.doi.org/10.1006/ eesa.2000.2014. PMid:11161694.

SUH, YH., TERASHIMA, A., PETRALIA, RS., WENTHOLD, RJ., ISAAC, JT., ROCHE, KW. and ROCHE, PA., 2010. A neuronal role for SNAP-23 in postsynaptic glutamate receptor trafficking. Nature Neuroscience, vol. 13, no. 3, p. 338-343. http://dx.doi. org/10.1038/nn.2488. PMid:20118925.

TOONEN, RF., DE VRIES, KJ., ZALM, R., SÜDHOF, TC. and VERHAGE, M., 2005. Munc18-1 stabilizes syntaxin 1, but is not essential for syntaxin 1 targeting and SNARE complex formation. Journal of Neurochemistry, vol. 93, no. 6, p. 1393-1400. http:// dx.doi.org/10.1111/j.1471-4159.2005.03128.x. PMid:15935055.

TOWBIN, H., STAEHELIN, J. and GORDON, J., 1979. Electrophoretic transfer of proteins from polyacrylamide gels to nitrocellulose sheets: procedure and some applications. Proceedings of the National Academy of Sciences of the United States of America, vol. 76, no. 9, p. 4350-4354. http://dx.doi. org/10.1073/pnas.76.9.4350. PMid:388439.

US Environmental Protection Agency - EPA, 1985. EPA-600/485-013: Methods for measuring the acute toxicity of effluents to freshwater and marine organisms. Washington, DC.: EPA. 159 P.

WU, LG., HAMID, E., SHIN, W. and CHIANG, HC., 2013. Exocytosis and endocytosis: modes, function, and coupling mechanisms. Annual Review of Physiology, vol. 76, p. 301-331. PMid:24274740. 